\title{
Monetary Policy Transmission Mechanism in Namibia: A Bayesian VAR Approach
}

\author{
Johannes P S Sheefeni \\ Department of Economics, University of Namibia, Namibia \\ peyavali@gmail.com
}

\begin{abstract}
This study analyzed the interest rate channel, credit channel, exchange rate channel and asset price channel for monetary policy transmission mechanism in Namibia. The idea behind this study is to have a comprehensive study that covers a variety of channels for monetary policy transmission mechanism. The study utilized a Bayesian vector autoregression (BVAR) technique on quarterly time-series data covering the period 2000:Q1 to 2016:Q4. In particular, the validity of the data used is checked and verified by using two sets of prior distributions suggested by Sims and Zha as well as prior distribution of Koop and Korobilis. The variables used in this study are real output $\left(\mathrm{Y}_{t}\right)$, real effective exchange rate $\left(\mathrm{E}_{t}\right)$, inflation rate $\left(\mathrm{P}_{t}\right)$, repo rate $\left(R_{t}\right)$, housing price index $\left(H_{t}\right)$ and credit extended to private sector $\left(L_{t}\right)$. The findings revealed that interest rate and credit channels remain important in the transmission mechanism to this day. Notably the exchange rate and asset price channels are also slowly gaining prominence in monetary policy transmission mechanism. Therefore, the study provides useful information to the monetary authorities regarding the process of transmission mechanisms. This is quite important especially that the Central Bank (Bank of Namibia) is very serious about financial stability within the financial system, given the fragility of the financial systems in the world due to financial crisis.
\end{abstract}

Keywords: central bank, monetary policy, Bayesian VAR, Namibia

\section{Introduction}

Namibia's monetary policy arrangement dates back at time of independence in 1990. In particular, Namibia's monetary policy conduct in Namibia involves a fixed exchange rate regime as an agent used to control inflation in order to maintain financial stability (Sheefeni, 2013). The option of fixed exchange rate regime is in-line with Namibia's decision to remain within the Common Monetary Area (CMA). This arrangement is formerly known as Rand Monetary Area, which consisted of Botswana, Lesotho, Swaziland and South Africa. Botswana moved out in 1976 and Namibia joined in 1990 after attaining her independence. The Common Monetary Area is now comprised of the following members Lesotho, Swaziland, Namibia and South Africa. It follows that the decision to remain in the CMA suggests abandonment of discretionary monetary policy, while giving more priority to maintaining a fixed peg against the rand (BoN, 2000). In 1993, Namibia introduced its own currency the Namibia dollar which was effectively pegged to the South African rand on par. However, in 1992, there was already a separate bilateral agreement between the two countries regarding the features of the peg arrangement (Kalenga, 2001). The bilateral agreement provides that "either contracting party has the right to issue its own national currency" (BoN, 2000). Specifically, Article 4, Section 1 of the Bilateral monetary agreement, states that, "Against the aggregate amount of Namibian dollar currency issued by the Bank of Namibia, the Bank of Namibia shall maintain a reserve equivalent thereto in the form of Rand assets and freely usable foreign currencies in such proportion as the Bank of Namibia considers appropriate..." (BoN, 2000). The section emphasis the need to fulfill the backing rules, which is why the 1993 peg was on par though the rand remained legal tender in Namibia (Kalenga, 2001).

The two dominant features of the bilateral agreement are: (1) a commitment to convert the Namibia dollar to South African rand at a fixed exchange rate, and (2) an explicit requirement that the BoN monetary liabilities be backed by the South African rand or other foreign assets (Kalenga, 2001). It should be noted that although there is a fixed parity between the two currencies, it is not irrevocable (Tjirongo, 1995). The pegging the exchange rate arrangement serves as a nominal anchor that can help in controlling domestic inflation (Mishkin, 1998). In the case of Namibia, the decision was influenced by the shared historical trade relations and close ties between the two countries. Thus, it was seen deemed fit that the SA rand provides a stable anchor for low inflation in Namibia (Kalenga, 2001). However, the implication of this setting is that Namibia's monetary policy is by default determined by South Africa taking away the discretionary of independent monetary policy conduct, making it difficult to assess monetary policy transmission mechanisms in Namibia. Interestingly, there are instances where the BON has sometimes opted for tight monetary policy for the sake 
of defending the exchange rate in the absence of inflationary pressures or in the absence of serious heated economic activities. Therefore, it is against this background that the paper sought to evaluate the channels for monetary policy transmission mechanisms in Namibia. The paper is organized as follows: the next section presents a literature review. Section 3 discusses the methodology. The empirical analysis and results are presented in section 4 . Section 5 concludes the study.

\section{Literature Review}

The theoretical literature discusses a number of channels of monetary policy transmission. However, they are broadly categorised into four main ones namely, interest rate, credit, exchange rate and asset price channels. The interest rate channel is founded on the macroeconomic models of investment developed in the mid- $20^{\text {th }}$ century. In particular it is based on the neoclassical models of investment developed by Jorgenson (1963) and Tobin (1969). According to Boivin, Kiley and Mishkin (2010), for investment, the key channel for monetary policy transmission is the direct interest rate operating via the user of capital. In this regard, there are factors that determine effects of monetary policy operating through these direct user cost channels. For example, the horizon over which interest rates influences spending. This is so because capital assets have a long life span and any adjustments of these stocks involve costs, which are considered when incorporating changes in interest rates into investment decisions. It is from this viewpoint that it has been argued that it is the real interest rate (which is the cost of capital) and the expected real appreciation of the capital asset that influence spending related to the expected life of the asset (Boivin et al., 2010).

The preceding relationship has been formalised by traditional econometric models by including the long-term interest rate in the user cost formula. This is because the monetary transmission mechanism involves the link between short- and long term-interest rates through expectation hypothesis of the term structure of interest rate. Therefore, the key channel through which monetary policy actions are transmitted to the economy and their effects on market interest rates is better known as the interest rate channel of the monetary policy transmission (MPT). However, Roley and Sellon (1995) argued that the connection between monetary policy actions and long-term rates is not a clear-cut to be particular it is weaker and less reliable. Other authors, such as Taylor (1995), have also highlighted the conflict on the magnitude of the impact of short-term and long-term rates on economic activity. Intuitively, for long-term decisions such as investing in plants and equipment, the long-term interest rate matters most. In line with the previous argument, the expectations hypothesis of the term structure postulates that, a policy change in the short-term interest rate is then transmitted to medium- and long-term interest rates through the balancing mechanism of supply and demand in the financial markets (Goeltom, 2008; Boivin et al., 2010). It is in this view that monetary policy affects long-term interest rates by manipulating short-term interest rates. This in turn results in changing market expectations of future short-term rates (Walsh, 2003). However, the market segmentation theory of the term structure of interest rates infers that the relationship between interest rates of different maturities is unnecessary, because investors and borrowers have strong maturity preferences that they intend to achieve when they invest. Therefore the major factors that determine the interest rate for a maturity segment are supply and demand conditions unique to the maturity segment.

The second channel of monetary policy transmission is the credit channel. In discontentment with how the effects of the interest rate explain the impact of monetary policy on expenditure on long-standing assets, resulted in a view of the monetary transmission mechanism that emphasises asymmetric information in financial markets. Mishkin (1996) indicates that information problems also refer to matters pertaining to costly verification and enforcement of financial contracts. In this regard, the most talked about channel that are resultant of information problems in credit markets are the bank lending and the balance-sheet channel. The bank lending channel is founded on the basis that banks play a special role in the financial system because they are suitable to deal with asymmetric information problems in credit markets. Gertler and Gilchrist (1993) indicate that the bank lending channel is based upon two critical assumptions. Firstly, bank loans and other non-bank assets such as commercial paper are imperfect substitutes, because of imperfect information in credit markets. Small firms are largely dependent on bank loans because of difficulties to obtain funds through other means, such as issuing securities or bonds, owing to high screening and monitoring costs (Markidou \& Tapia, 2003). Therefore, the unwillingness by the bank to offer credit will have repercussions in terms of spending by the dependent customers. This in turn translates into lower aggregate 
demand. Secondly, through change in monetary policy, the central bank has the ability to constrain the supply of bank loans through change in monetary policy. For instance, a monetary policy contraction leads to a reduction in bank reserve money and the number of loans, hence bringing about a fall in spending by bankdependent customers. It is in view of this that monetary policy contraction leads to a reduction in the supply of bank loans and in turn affects real economic activity.

The balance sheet channel is a resultant of a decline in the importance of the bank lending channel (Mishkin, 1996). Introduced by Bernanke and Gertler (1989), the balance sheet channel is normally coupled with the outcome of a policy-induced change in interest rates on the cash flows and hence the balance positions of non-financial firms that are heavily dependent on bank loans (Afandi, 2005). For example, a contraction in monetary policy in the form of a rise in interest rates is a cost because it brings about an increase in interest expenses for the firm. This leads to a reduction in its cash flows, hence weakening its balance sheet position. On the contrary, an expansionary monetary policy yields opposite results. However, if interest rates increase further, it leads to a reduction in asset prices, which in turn lowers the value of collateral. The implication here is that lower collateral is a risk to the lender which also suggests that losses from adverse selection are higher, so as moral hazard. That is to engage risky investment projects by owners with lower equity stake in a firm. Lower collateral are usually associated with lower net worth which by implication also leads to a decrease in lending to finance investment spending (Mishkin, 1996).

From the households perspective, declines in bank lending cause a decline in durable and housing purchases by consumers, who are limited when it comes to access to alternative sources of credit. Similarly, an increase in interest rates causes deterioration in household balance-sheets because consumers' cash flow is adversely affected (Mishkin, 1996). Furthermore, the effects of the balance-sheet channels can also be explained via liquidity effects on consumer durable and housing expenditure. The importance of balance-sheet effects is their impact on consumers' desire to spend as opposed to lenders' desire to lend. The argument is that because of asymmetric information about their quality, consumer durables and housing are very illiquid assets (Mishkin, 1978). Therefore, the illiquidity of consumer durable and housing assets is another reason why a monetary contraction, which raises interest rates and thereby reduces cash flow to consumers, leads to a decline in spending on consumer durables and housing. It can be concluded that a decline in consumer cash flow increases the likelihood of financial distress, which in turn reduces the desire of consumers to hold durable goods or housing, thus reducing spending on these items, and consequently aggregate output.

The third channel of transmission mechanism is that of the exchange rate. This mechanism works directly via its effect on import prices to aggregate demand via net exports (Ramos-Francia and Sidaoui, 2008). The analysis of this channel of transmission can be categorised into two parts: (i) the pass-through from the monetary policy rate to the exchange rate and (ii) the pass-through from the exchange rate to the real economy. A policy rate change by the central bank also induces a change on return on local/domestic investments relative to foreign investments. The interest rate differential leads to capital outflows and affects the relative exchange rate. Therefore, central banks make serious attempts to maintain stable interest rate differential in order to facilitate capital account stability and to abate volatility of the bilateral exchange rate. With regards to pass-through from the exchange rate to inflation and the real economy, changes in the exchange rate are directly transmitted to the consumer price through the cost of imported inputs and finished goods. However, the magnitude and speed of the pass-through depend on prevailing demand conditions, price adjustment costs and the perceived persistence of the depreciation/appreciation. The indirect transmission has lag effects through changes in the levels of demand (between domestic goods and import substitutes). This comes as a result of shifts in the country's external competitiveness or inflation expectations (Ramos-Francia and Sidaoui, 2008).

In general, the exchange rate channel examines the relationship between net private capital inflows and monetary policy under the two extreme categories, namely the fixed and flexible exchange rate regimes. Karamanou, Mahadeva, Robinson and Syrichas (2017) discussed the two alternatives. Under a flexible exchange rate regime monetary tightening in the form of interest rate hike, makes local currency deposits more enticing, resulting in appreciation of a currency. The consequence of high valued currency is that it makes local goods more expensive than foreign goods which result in a drop in net exports and consequently aggregate output. However, under the fixed exchange rate with no capital controls, monetary tightening will 
cause capital inflows. This is so because of the attractiveness of a higher domestic interest rate to international investors. Thus the central bank responds by growing its foreign exchange reserves in hope to forcefully reduce the interest rate down to its original level. Thus, in the presence of fixed exchange rate or heavily managed, the effectiveness of monetary policy action is reduced but not necessarily entirely eliminated.

The authorities still have some room for manoeuvring. In particular, there are two ways in which monetary policy can maintain some degree of independence in the case of a fixed exchange rate regime. First, under the incomplete fixed exchange rate regime with some capital controls, where there is no substitutability of domestic and foreign assets, may enable the central bank interest rates to diverge from the levels of the interest rate parities. This is true for as long as the exchange rate does not reach the zone's boundaries. Secondly, monetary policy can affect the real exchange rate via the price level, provided there is no perfect substitutability between domestic and foreign assets, allowing domestic interest rates to deviate from international levels. In this way, monetary policy can affect the real exchange rate through prices while holding the nominal exchange rate fixed. Furthermore, via this channel the monetary authorities can affect net exports at a limited degree but with much longer lags. Therefore, capital controls and imperfect substitutability of domestic and foreign assets, along with a target zone regime, create a channel for monetary policy to affect output and prices despite a fixed exchange rate system (Bitans, Stikuts and Tillers, 2003).

The fourth channel focuses on the simulating effect of higher asset prices (such as equities and housing) on household consumption and aggregate demand (Mishkin, 2004; Pedram, Shirinbakhsh and Afshar, 2011; Huang, 2012). This concurs with the monetarist view that the concentration should focus on all relative asset prices and real wealth. The effect of asset prices extends beyond those operating through interest rates, exchange rates and equity prices (Metzler, 1995). The effect of monetary policy shocks on market interest rates affects both the short-term and long-term interest rates. This is because economic agents expect delay in reversed monetary policy actions. Accordingly, changes in long-term interest rates could have an impact on asset prices to an extent that depends on the expectations of other variables affecting those prices and on expected future policy actions (MPC, 2003). For example, a decline in monetary policy can lead to a decline in land and property values, which in turn leads to a decline in household wealth and thus a decline in consumption and aggregate output. In fact, Taylor (1995) argued that changes in long-term interest rates influences the price of financial assets and the price of physical assets such as durable consumption goods, real estate and business equipment. Thus, changes in the prices of these assets will alter individuals' spending and savings decisions and consequently, affect real income and the inflation rate (Pedram et al., 2011).

Various studies have empirically looked at monetary policy transmission mechanisms to determine whether there is conformity and compatibility between the theoretical propositions with the empirical outcomes and if not, what the possible reasons could be. Uanguta and Ikhide (2002) examined monetary policy transmission mechanisms in Namibia using monthly data for the period 1990 to 1999. Two channels (interest rate and credit channels) were investigated by employing two methods were applied to obtain the results, namely the cumulative forecast error variance and a general (unrestricted) vector autoregression model. The findings are that monetary policy tightening causes lending rates to increase in the domestic economy. This in turn leads to a decline in private investment, resulting in negative impacts on output and employment in the short run. These results showed that both channels were effective in the case of Namibia. A study by Bitans, Stikuts and Tillers (2003) examined the transmission of monetary shocks in Latvia. It dealt in particular with short-term reactions of the economy to various monetary shocks. The importance of various channels of monetary transmission was tested empirically by using the structural vector autoregression (SVAR) model and small structural macroeconomic model using monthly data for the period January 1995 to March 2002. The analysis provided evidence that monetary shocks were transmitted to the economy mainly through the exchange rate channel. The analysis of the financial system of Latvia supported the view that the wealth channel was very weak or even non-existent at the time because of a relatively underdeveloped capital market.

A study by Muco, Sanfey and Taci (2003) examined the conduct of monetary policy in Albania during the transition period. By employing the VAR model, the study identified various channels through which monetary policy could affect prices and output and established their relative importance. This study used 
monthly data for the period January 1994 to May 2003. Estimates from a VAR model of key macroeconomic variables demonstrated the weak link between money supply and inflation up to mid-2000. However, the move during 2000 from direct to indirect instruments of monetary control helped to strengthen the predictability of the transmission link from money supply to inflation. Hence the conclusion that external influence, by contributing to exchange rate stability, had played an important part in keeping inflation low for most of the transition period. Moreover, the introduction of indirect instruments of monetary policy appeared to have contributed to the effectiveness of the exchange rate transmission mechanism of monetary policy into the real economy. The preceding results concur with that of Chow (2004) for Singapore where the VAR model was estimated using monthly data for the period January 1989:1 to October 2003. The study used the real effective exchange rate as a measure for monetary policy and finds that output reacts immediately and significantly to a contractionary monetary policy shock. Therefore, the study finds that the exchange rate channel was more effective in transmitting monetary policy to the economy than the interest rate channel. Ngalawa (2009) investigated how monetary policy action affects consumer prices and output in Malawi by employing a technique of innovation accounting in an SVAR model. The study used monthly time series data for the period January 1988 to December 2005. Effectively, the country employed hybrid operating procedures where the officials were targeting reserve money and short-term interest rates. However, the findings revealed that the bank rate proved to be more effective then reserve money as a monetary policy instrument affecting both price stability and high growth and employment objectives.

Spulbar, Nitoi and Stanciu (2012) investigated the transmission mechanism of the monetary policy in Romania. The study employed the Bayesian vector autoregression (BVAR) on monthly data for the period 2001 to 2010. The results revealed that the exchange rate is effective in affecting the real economy. However, the interest rate channel of is being more and more consistent in the last years. Similarly, Atabaev and Ganiyev (2013) also analyzed the effects of monetary transmission on real output and price level in Kyrgyzstan. In particular, the study used monthly data for the period 2003 to 2011 to analyze the relationships between the money supply, real output, price level, interest rate, credit and real exchange rate using VAR. The findings showed that the interest rate channel remains weak, the credit channel has some affects to real output while the exchange rate channel affects the prices. Exchange rate channel remains still the most effective channel. In South Africa, Gumata, Kabundi and Ndou (2013) investigated the different channels of transmission of monetary policy shock in a data-rich environment. The study utilized a Large Bayesian Vector Autoregression model with 165quarterly variables observed from 1990Q1 to 2012Q2. The model included five channels of transmission: credit, interest rate, asset prices, exchange rate, and expectations. The results revealed that all channels seem effective though their magnitudes and importance differ. Furthermore, the results reveal that the interest rate channel is the most important transmitter of the shock, followed by the exchange rate, expectation, and credit channels. The asset price channel is somewhat weak.

Rosoiu and Rosoiu (2013) analyzed the importance of the interest rate and exchange rate channels for the emerging countries Romania, Poland, Czech Republic and Hungary. The study employed BVAR approach with Diffuse priors on quarterly data over the period 1998:Q1 to 2012:Q3. The results revealed that both channels are effective for the monetary policy transmission mechanism in Hungary and Czech Republic. In Romania and Poland they do not exhibit puzzles, but the impact of the macroeconomic variables is not very significant and shows very high volatility. In the context of monetary integration, exchange rate channel will become irrelevant when these countries adopt Euro currency. This change will lead instead to a powerful interest rate channel. Sheefeni (2013) investigated the role of monetary policy in Namibia for the period 1993 to 2011. The study specifically analyzed the relative importance of the different channels of monetary policy transmission using a SVAR and SVECM on quarterly data. Furthermore, the study also examined the exchange rate pass-through from exchange rate to domestic prices using both SVAR/SVECM and the single equation error correction model (ECM). Estimation results on the different channels of monetary policy transmission mechanism showed that the interest rate channel and the credit channel are effective in transmitting monetary policy actions. The exchange rate channel is also operative but not effective. The money effect model confirms that inflation in Namibia is not a monetary phenomenon. The results of the pass-through relationship showed that there is an incomplete but high exchange rate pass-through from exchange rate to domestic prices. Hai and Trang (2015) analyzed monetary transmission mechanism in Vietnam by using a VAR, focusing especially on how the economy dynamically responds money demand, interest rate, exchange 
rate, and asset price shocks. The study used quarterly data for the period 1995-2010 to examine the different channels of monetary policy mechanism in Vietnam. The empirical results show money demand and interest rates account for a major part of variations in output. And output is affected by monetary tightening in some lags, bottoming out after 5-6 quarters.

Mwabutwa, Viegi and Bittencourt (2016) analyzed the evolution of monetary transmission mechanism in Malawi for the period 1981 and 2010 using a Bayesian Time Varying Parameter Vector Autoregressive (TVPVAR) model with stochastic volatility. In specific terms, the study evaluated the responses of real output and general price level to bank rate, exchange rate and credit shocks have changed over time since Malawi adopted financial reforms in 1980s. The results showed that inflation and real output responses to monetary policy shocks changed over the period under the review. Importantly, beginning mid-2000s, the monetary transmission performed consistently with predictions of economic theory partly due to stable macroeconomic conditions and positive structural changes in the economy. However, the statistical significance of the private credit supply remains weak and this calls for more financial reforms targeting the credit market which can contribute to monetary transmission and promote further economic growth in Malawi. Similarly, Mabulango and Boboy (2016) also examined the monetary policy transmission mechanism in the Democratic Republic of Congo using monthly data for the period January 2003 to December 2015. A restricted Bayesian VAR framework was used following Sims and Zhao (1998); Brandt and Freedman (2006) and Koop and Korobilis (2010) restrictions. This was done with the aim of investigating the short-run dynamic responses of output and inflation to interest and exchange rate innovations. The results reveal that the interest rate channel remains weak. Moreover, the transmission mechanism through the exchange rate channel has been found more pronounced during the recent period of macroeconomic performance.

There are lessons to be learnt from these studies. Firstly, there are similarities in the sense that some studies find the interest rate, credit, exchange rate and asset price channels to be effective. Other studies find the opposite. However, there are variations in the significance of the impact. Secondly, there are also variations in econometric techniques employed in analyzing the interrelation among all channels of the transmission mechanism. This is common across developed countries, emerging markets and quasi-emerging markets. In the case of Namibia, the only study that comes close to the issue of monetary policy transmission is that of Uanguta and Ikhide (2002). However, this study only looked at interest rate and the credit channel, leaving a gap by not examining the exchange rate and asset price channels. Furthermore, Sheefeni (2013) comprehensive model of analysing the interest rate, credit and exchange rate channels, leaving out the asset price channel creates a gap in the literature. The two studies provide useful insights on the three channels of monetary policy transmission in Namibia. The question still remains about monetary policy transmission mechanism of a comprehensive model that includes the asset price channel. Therefore, this calls for a study that is inclusive of interest rate, credit, exchange rate and assets price channels. Thus, this study intends to fill this gap.

\section{Methodology}

Empirical Framework: This study estimates a Bayesian vector autoregression model to analyse monetary policy transmission mechanism in Namibia as it was used by Spulbar, Nitoi and Stanciu (2012). This approach is appropriate for small open economies where monetary policy has been criticized because of abnormalities such as liquidity as well as price or exchange rate puzzles (Rosoiu and Rosoiu, 2013). The second problem is that of over-parameterization, particularly, in the presence of a large number of parameters to be estimated while faced with too few observations. This problem can be addressed by using Bayesian methods were developed (Rosoiu and Rosoiu, 2013; Mabulango and Boboy, 2016).In light of the above, this justifies the use of this methodology as opposed to the standard vector autoregression used in most empirical studies. Firstly, the validity of the data used is checked and verified by using two sets of prior distributions suggested by Sims and Zha (1998) as well as prior distribution of Koop and Korobilis (2010). This can be explained in the following manner. Consider the following VAR (p) model:

$y_{t}=a_{0}+\sum_{i=1}^{p} A_{l} y_{t-1}+\varepsilon_{t} \quad \varepsilon_{t} \sim N(0, \Sigma)$

Where $y_{t}$ is an $m \times 1$ vector of $t=1, \ldots \ldots \ldots, T$ observations on $m$ time-series variables, $a_{0}$ is a $m \times 1$ vector of intercepts and $A_{l}$ is a $m \times m$ matrix of regression coefficients for the $l_{t h}$ lag with the pmaximum numbers of 
lags. Furthermore, $Y$ can be defined to be a $T \times 1$ matrix which stacks the $\mathrm{T}$ observations on each dependent variable in columns next to one another. Specifically by denoting:

$x_{t}=\left[\begin{array}{llll}1 & y_{t-1} & \ldots & y_{t-p}\end{array}\right], X=\left[\begin{array}{c}x_{1} \\ \vdots \\ x_{T}\end{array}\right], \quad B=\left[\begin{array}{c}a_{0} \\ A_{1} \\ \vdots \\ A_{p}\end{array}\right]$,

and $\beta=\operatorname{vec}(B)$, the VAR model can be rewritten:

$y_{m T \times 1}=X_{T \times(m p+1)} B_{(m p+1) \times m}+E_{T \times m}$

The debate surrounding the choice of prior distribution still remains a bone of contention, particularly in Bayesian analysis. When one chooses the Sims-Zha prior, equation (1) can be rewritten as:

$y_{t}=c+\sum_{i=1}^{p} y_{t-1} B_{1}+u_{t} \quad u_{t} \sim N\left(0, I_{M}\right)$

where $\Sigma=A_{0}^{-1} A_{0}^{-1}$ and $A_{0}$ is non-singular. By denoting:

$B=\left[\begin{array}{c}B_{1} \\ \vdots \\ B_{p} \\ c\end{array}\right], c=a_{0} A_{0}^{-1}, B_{1}=A_{+} A_{0}^{-1}, u_{t}=\varepsilon_{t} A_{0}^{-1}$,

This model can be related to the reduced form of equation (2). It follows that, using Sims-Zha notations, the model can be written compactly as follow:

$Y A_{0}-X A_{+}=U$

$Z A-U$

where $Z=[Y-X]$ and $A=\left[\begin{array}{l}A_{0} \\ A_{+}\end{array}\right]$

Unlike the independent hyper prior specification (that is, $\pi\left(A_{0}\right) \pi\left(A_{j}\right)$ ), Sims and Zha suggest the conditional prior (Sims-Zha prior):

$\pi(A)=\pi\left(A_{0}\right) \pi\left(A_{+} \mid A_{0}\right)=\pi\left(A_{0}\right) \phi\left(B_{0}, \Psi_{0}\right)$

where $\pi($.$) is a marginal distribution of A_{0}$, while $\phi($.$) is the standard normal density with mean B_{0}$ and covariance $\Psi_{0}$. Each element of $\Psi_{0}$ is written as:

$\Psi_{0 l, i j}=\left(\frac{\lambda_{0} \lambda_{1}}{\sigma_{j} l^{\lambda 3}}\right)^{2} \quad i, j=1, \ldots, m$

where $\sigma_{j}^{2}$ is the $j$ th element of $\Sigma$ for the $l$ th lag of variable $i$ in equation $j$. Moreover, the hyperparameters such as $\lambda_{0}, \lambda_{1}$ and $\lambda_{3}$ represent the general accepted beliefs about the series being modelled. In principle, the idea is to shrink all equations around a random walk with a drift for variables that show persistence and around white noise for variables that are mean-reverting. This takes care of the problem of over fitting the data. It is very simple and attractive (Gumata, Kabundi and Ndou, 2013). For a detailed description and discussion of the hyper parameters of Sims and Zha prior see Brandt and Freedman (2006). In estimating the model using Sims and Zha prior, the study will use a Normal-Wishart prior distribution.

As indicated earlier, the study will also estimate the model employing the Ko-Ko Minnesota/Litterman prior (2010). This approach assumes that $\Sigma$ is known. The prior for $\beta$ is given by:

$\beta \sim N\left(\beta_{0}, \underline{V}\right)$

With mean $\beta_{0}=0$ and covariance $\underline{V} \neq 0$.Koop and Korobolis specified the prior covariance matrix $\underline{V}$ as a diagonal matrix with its elements $V_{i j, l}(i=1, \ldots, p)$.

$V_{i j, l}=\left\{\begin{array}{c}a_{1} / p^{2} \text { for coefficients on own lags } \\ \left(a_{2} \sigma_{i}\right) /\left(p^{2} \sigma_{j}\right) \text { for coefficients on lags of variable } i \neq j \\ a_{3} \sigma_{i} \text { for coefficients on exogenous variables }\end{array}\right.$

Where $\sigma_{i}^{2}$ is the ith diagonal element of $\Sigma$.

The two models are estimated using Bayesian techniques.

Data and Data Source: This paper used quarterly data covering the period 2000:Q1 to 2016:Q4. The nature of the work requires secondary data which were sourced from Bank, Bank of Namibia (BoN) statistical bulletins (various issues), First National Bank Namibia and Namibia Statistics Agency (NSA). The data for the 
following variables were collected, real gross domestic product $(\mathrm{Y})$, the real effective exchange rate (expressed as an index, this index growth indicating Namibia's real appreciation against the currencies of the trading partners) (E), the inflation rate (P), the total credit extended to the private sector (L), the interest (repo rate) (R) and the real house prices index $(\mathrm{H})$. All the data are expressed in natural logarithm. The period chosen is based on the fact that data of the real house index only started to be collected then and no data collected prior to the said period.

\section{Findings and Analysis}

Unit root: In testing for stationarity the Kwiatkowski-Phillips-Schmidt-Shin (KPSS) test was used. The series were found to be stationary in level form with the exception of real output and credit to the private sector; hence the null hypothesis of stationarity could not be rejected for the rest of the variables.

Table 1: Unit root tests: KPSS in levels and first difference

\begin{tabular}{lllll}
\hline Variable & $\begin{array}{l}\text { Model } \\
\text { Specification }\end{array}$ & $\begin{array}{l}\text { KPSS } \\
\text { Levels }\end{array}$ & First Difference & $\begin{array}{l}\text { Order } \\
\text { Integration }\end{array}$ \\
& Intercept & 1.043 & $0.102^{* *}$ & 1 \\
& $\begin{array}{l}\text { Intercept and } \\
\text { Trend }\end{array}$ & $0.107^{*}$ & $0.102^{* *}$ & 0 \\
$\mathrm{LNY}_{\mathrm{t}}$ & Intercept & $0.201^{* *}$ & $0.066^{* *}$ & 0 \\
& Intercept and & & & \\
& Trend & $0.107^{* *}$ & $0.051^{* *}$ & 0 \\
$\mathrm{LNE}_{\mathrm{t}}$ & Intercept & $0.194^{* *}$ & $0.080^{* *}$ & 0 \\
& Intercept and & & & \\
& Trend & $0.073^{* *}$ & $0.050^{* *}$ & 0 \\
$\mathrm{LNP}_{\mathrm{t}}$ & Intercept & $0.718^{* * *}$ & $0.095^{* *}$ & 0 \\
$\mathrm{LNR}_{\mathrm{t}}$ & Intercept and & & & \\
& Trend & $0.067^{* *}$ & $0.064^{* *}$ & 0 \\
& Intercept & $0.388^{* *}$ & $0.344^{* *}$ & 0 \\
$\mathrm{LNH}_{\mathrm{t}}$ & Intercept and & & & 0 \\
& Trend & $0.149^{* *}$ & $0.134^{* *}$ & 1 \\
& Intercept & 1.073 & $0.276^{* *}$ & \\
$\mathrm{LNL}_{\mathrm{t}}$ & $\begin{array}{l}\text { Intercept and } \\
\text { Trend }\end{array}$ & $0.190^{* * *}$ & $0.095^{* *}$ & 0 \\
\hline
\end{tabular}

Source: author's compilation and values obtained from Eviews

Notes: (a) ${ }^{* * *},{ }^{* *}$ and ${ }^{*}$ means the variable is stationary at $1 \%, 5 \%$ and $10 \%$ respectively.

The next step is then to difference once, the variables which were non-stationary in level form as shown in table 1. After differentiating the variables once, all the test statistics showed that the series are now stationary. Therefore, it can be concluded that the some variables are stationary at levels and others in first difference, implying that there is a mixture variables integrated of order zero I(0) and one I(1).

Table 2: Optimal Lag Order Selection Criteria

\begin{tabular}{lllllll}
\hline Lag & LogL & LR & FPE & AIC & SC & HQ \\
\hline 0 & 294.341 & NA & 3.681 & -9.301 & -9.095 & -9.221 \\
1 & 721.165 & 757.268 & 1.242 & -21.909 & -20.468 & -21.343 \\
2 & 805.861 & 133.874 & 2.662 & -23.479 & $\mathbf{- 2 0 . 8 0 3 *}$ & -22.429 \\
3 & 863.027 & 79.2946 & 1.462 & -24.162 & -20.251 & $\mathbf{- 2 2 . 6 2 7 ^ { * }}$ \\
4 & 899.024 & 42.964 & 1.732 & -24.162 & -19.016 & -22.141 \\
5 & 951.742 & $\mathbf{5 2 . 7 1 8 *}$ & $\mathbf{1 . 3 6 2} *$ & $\mathbf{- 2 4 . 7 0 1 *}$ & -18.320 & -22.196 \\
\hline
\end{tabular}

* indicates lag order selected by the criterion 
VAR Lag Order Selection Criteria: The information criteria for the lag order selection for the VAR system is presented in Table 2. These tests show the convergence on the lag length and that is the essence of the lag structure test. At the chosen lag length, all the inverse roots of the characteristic AR polynomial have a modulus of less than one and lie inside the unit circle, indicating that the estimated VAR is stable or satisfies the stability condition. First it is necessary to determine the number of lags, since this has a big effect in the analysis. There are five criteria: the sequential likelihood ratio (LR), Akaike information criterion (AIC), Schwarz information criterion (SC), final prediction error (FPE) and Hannan Quinn information criterion (HQ).

Impulse Response Functions: As stated earlier the impulse response functions where derived from the Bayesian VAR estimates based on the prior of Sims and Zha (1998) and that of KoKo Minnesota/Litterman (2010) prior. The channels estimated are the interest rate, exchange rate, credit and asset price channel of monetary policy transmission mechanism in Namibia. The BVAR models were introduced as alternatives as an alternative to the VAR technique (Spulbar et al, 2012).

\section{Figure 1: Interest Rate Channel - Minnesota}

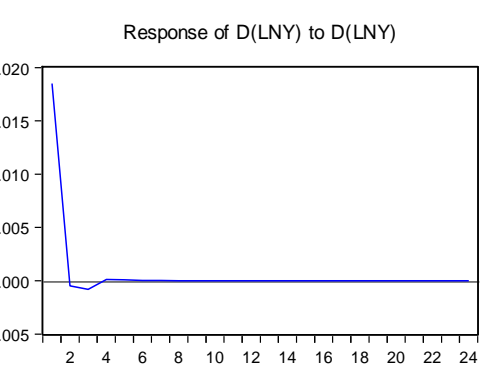

Response to Generalized One S.D. Innovations
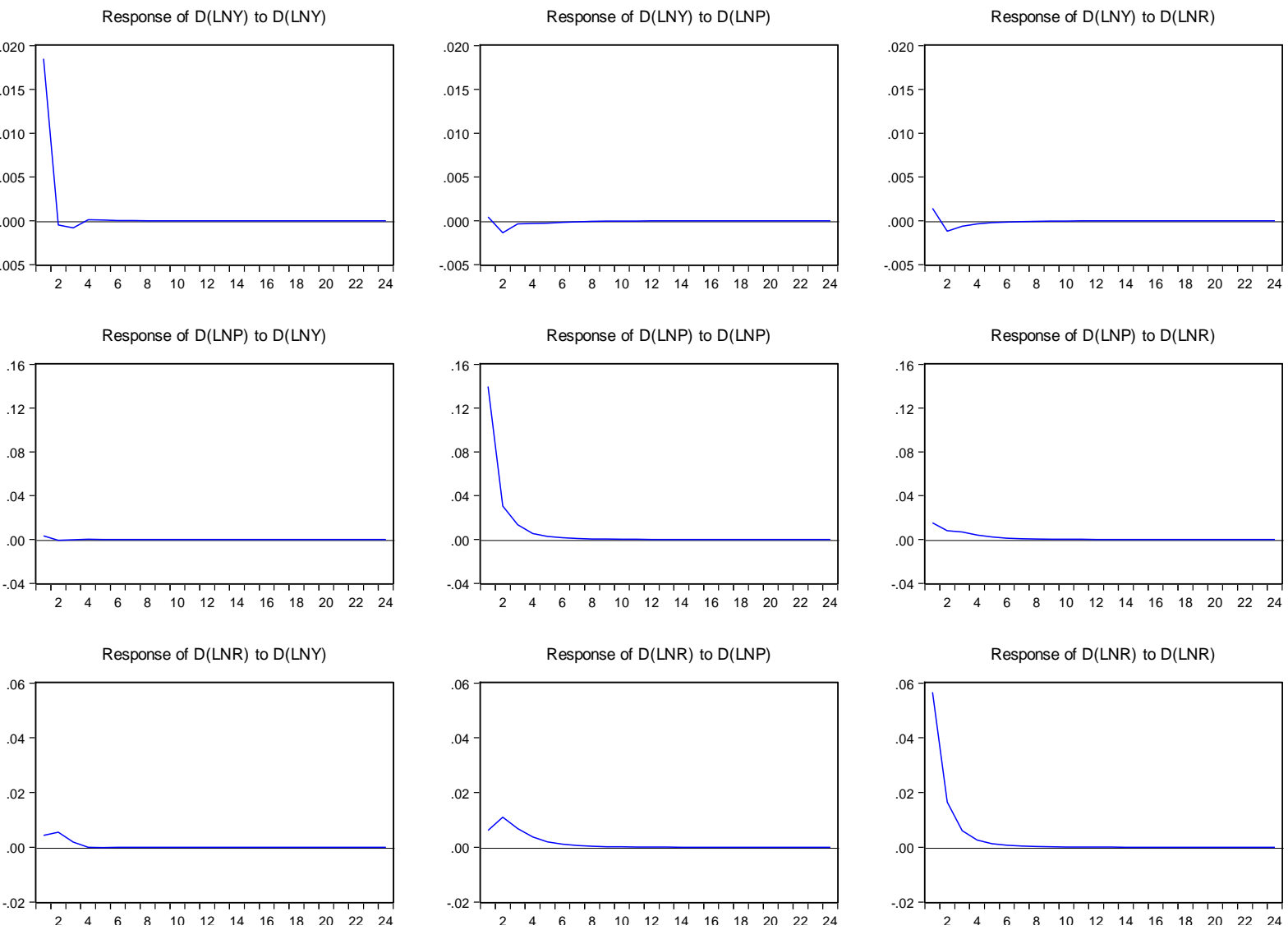

Figure 1 shows the results of the of impulse responses of output growth and inflation rate to interest rate innovation. In this regard, a positive shock in a form of a rise in the interest rate results in output growth declining up to 8 quarters. The effect is not persistent, thus it wears out after 8 quarters. This indicates that the monetary policy does have effect on output in the medium-term and not necessarily in the long-term. Similarly, inflation rate also responds negatively to shocks in interest rate, though not persistent. In particular, the effect also wears out after 8 quarters. These results are in agreement with those of Mabulango and Boboy (2016) who showed similar results for Democratic Republic of Congo. 
Figure 2: Exchange Rate Channel - Minnesota

Response to Generalized One S.D. Innovations

Response of $\mathrm{D}(\mathrm{LNY})$ to $\mathrm{D}(\mathrm{LNY})$

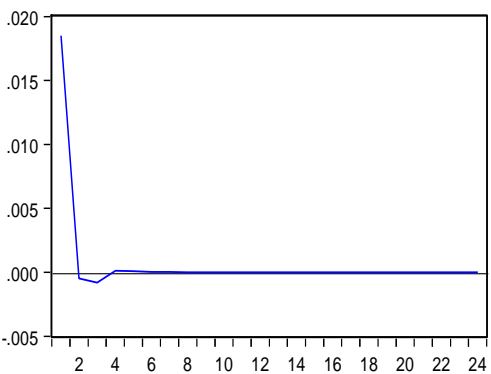

Response of $\mathrm{D}(\mathrm{LNP})$ to $\mathrm{D}(\mathrm{LNY})$

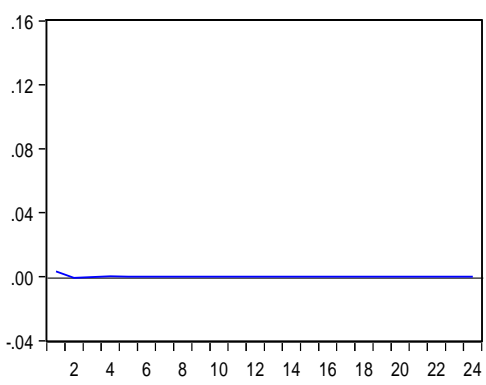

Response of $D(L N E)$ to $D(L N Y)$

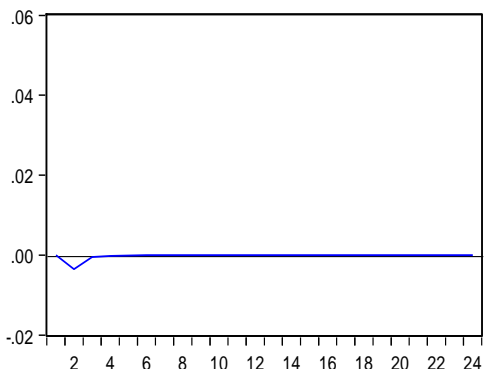

Response of $\mathrm{D}(\mathrm{LNY})$ to $\mathrm{D}(\mathrm{LNP})$

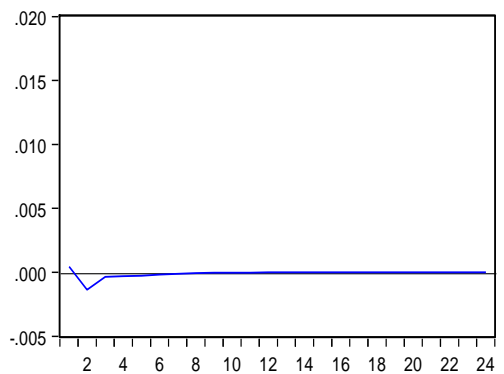

Response of $\mathrm{D}(\mathrm{LNP})$ to $\mathrm{D}(\mathrm{LNP})$

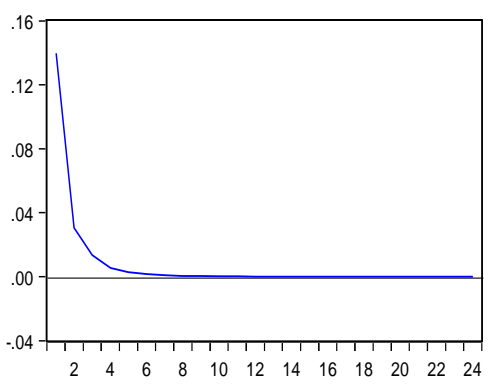

Response of $\mathrm{D}(\mathrm{LNE})$ to $\mathrm{D}(\mathrm{LNP})$

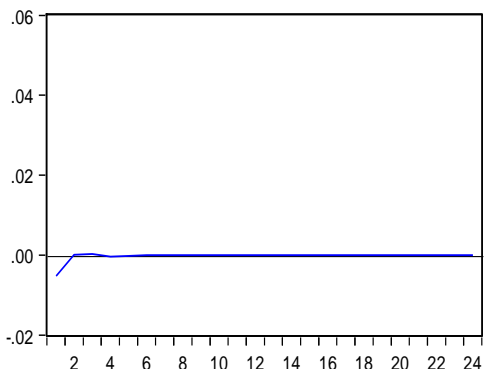

Response of $\mathrm{D}(\mathrm{LNY})$ to $\mathrm{D}(\mathrm{LNE})$

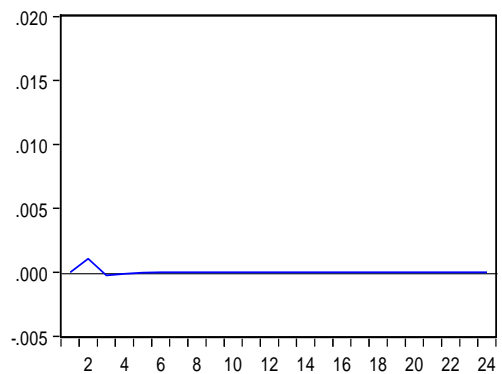

Response of $\mathrm{D}(\mathrm{LNP})$ to $\mathrm{D}(\mathrm{LNE})$

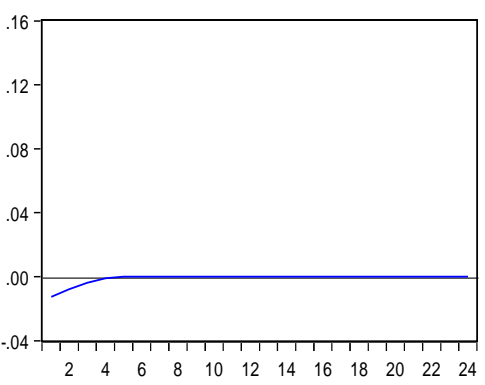

Response of $\mathrm{D}(\mathrm{LNE})$ to $\mathrm{D}(\mathrm{LNE})$

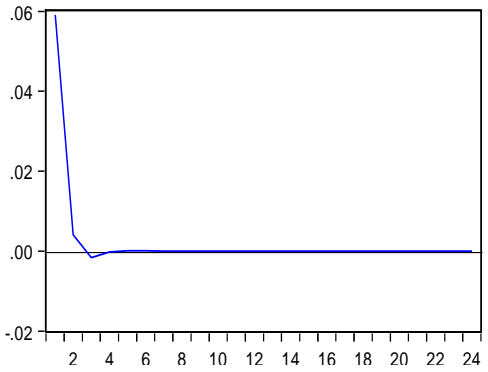

The results in figure 2 show that the effects of positive exchange rate shock on output and inflation. In this instance, a positive shock to exchange rate (an appreciation of exchange rate in Namibia), results in an increase in output initially increases which followed by a non-persistent decline in output after 3 quarters and the effects wears out after 6 quarters. In addition, an appreciation of exchange rate resulted in an increase in the inflation rate but on the negative grid, but the effects wore out 5 quarters. These results are similar to those of Mabulango and Boboy (2016) though the time horizons differ in the sense that they used monthly frequency. This is possible for Namibia due to the fact that Namibia is dependents on imports goods for its local production. Particularly, the shocks on exchange rate will immediately feed into prices of goods and services charged by producers who use imported inputs and consumers who purchase imported goods and services. The results for the credit channel reveals that a positive shock to credit results in a decline in both output and inflation rate as shown in figure 3. Interestingly, the effects wear out after 4 quarters in both cases. Again this illustrates the medium-term of monetary policy transmission mechanism as it is commonly recorded in literature for developing countries. 


\section{Journal of Economics and Behavioral Studies (ISSN: 2220-6140)}

Vol. 9, No. 5, pp. 169-184, October 2017

\section{Figure 3: Credit Channel - Minnesota}

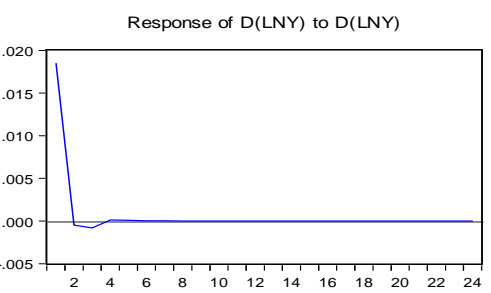

Response to Generalized One S.D. Innovations
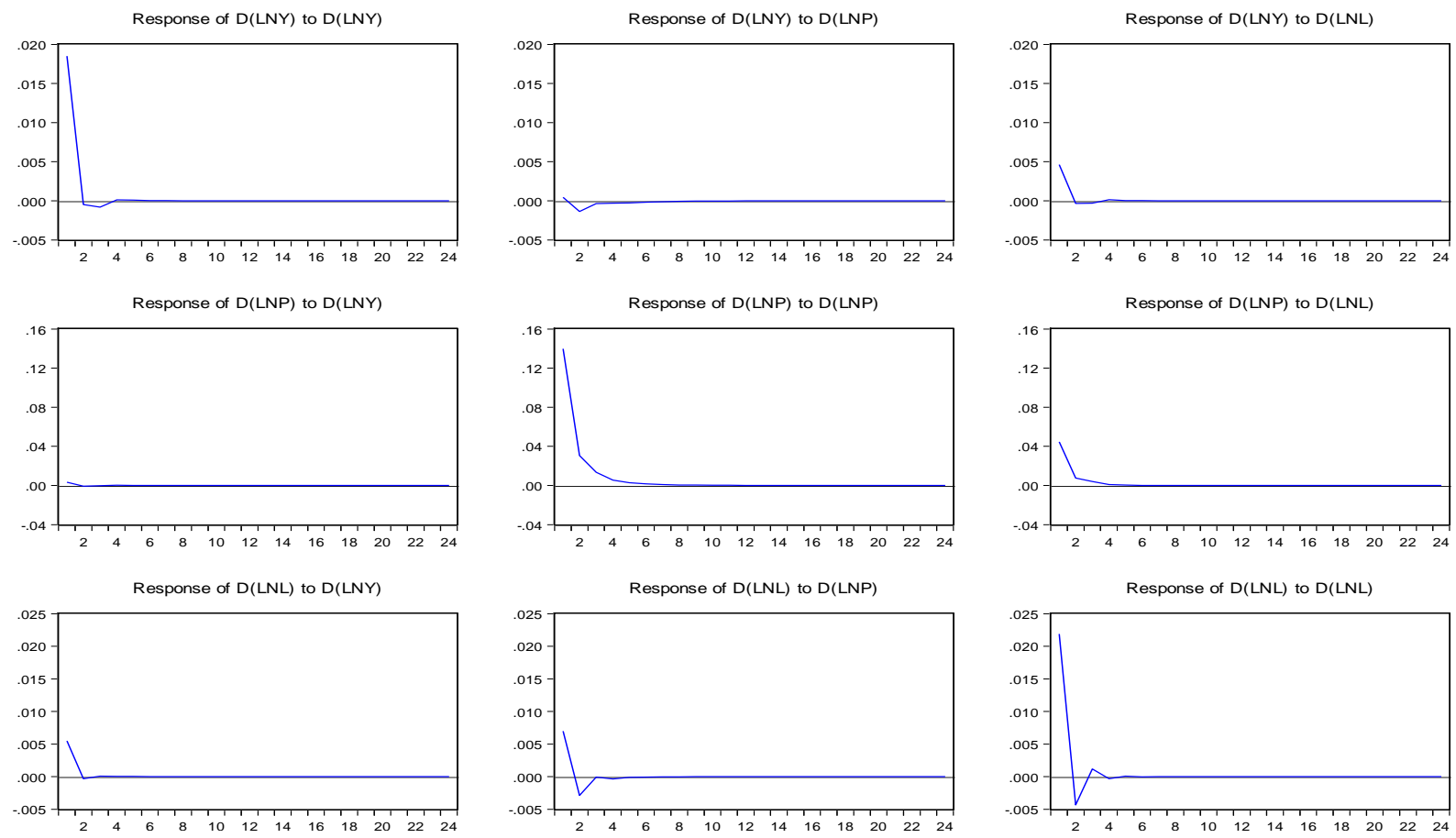

Figure 4: Asset Price Channel - Minnesota

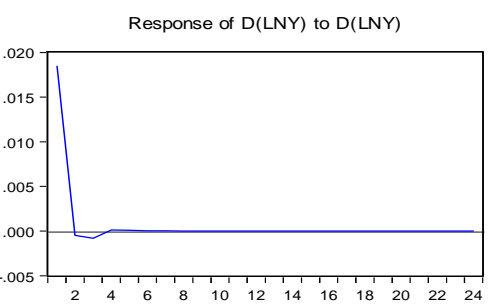

Response to Generalized One S.D. Innovations
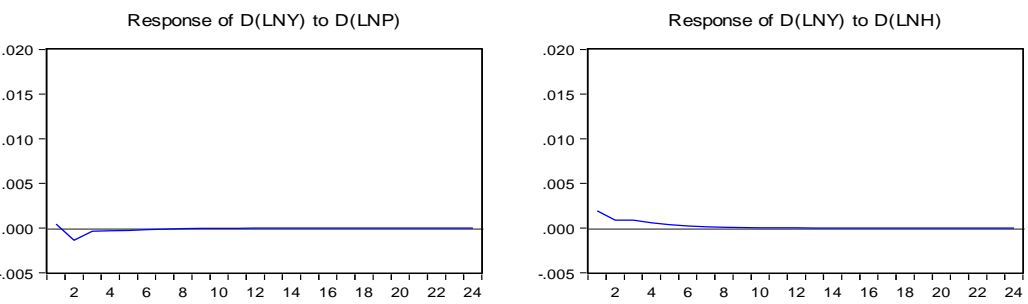

Response of $\mathrm{D}(\mathrm{LNP})$ to $\mathrm{D}(\mathrm{LNY})$
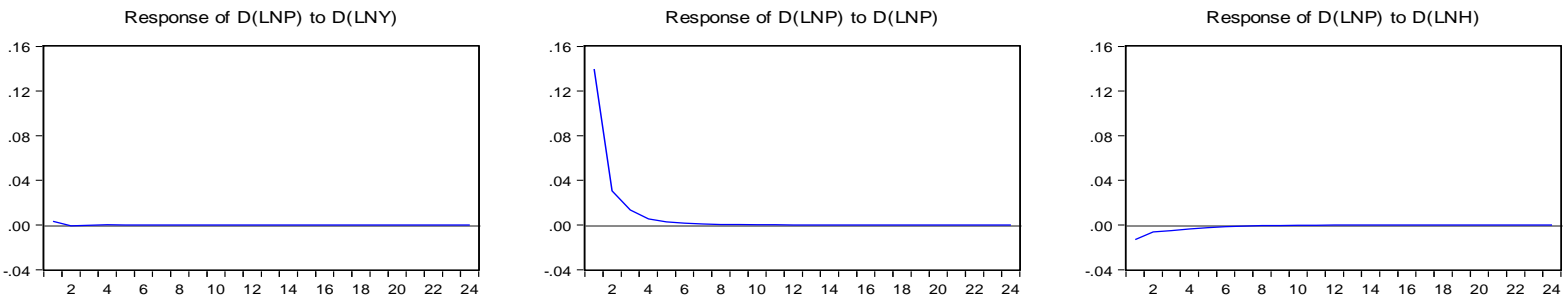

Response of $\mathrm{D}(\mathrm{LNH})$ to $\mathrm{D}(\mathrm{LNY})$
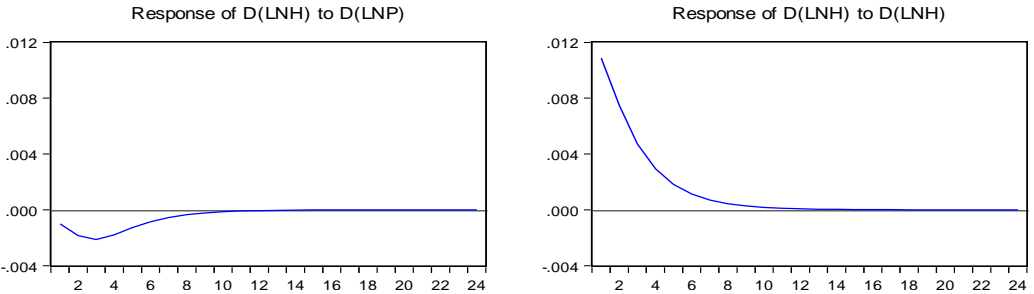

Notably, output responded negatively to the shocks to housing prices and the effects wear out after 7 quarters. On the contrary, inflation rate responded positively though the persistence dies out after 5 quarters as reported in figure 4 . The responses do not appear to be of great magnitude as it is with most empirical 


\section{Journal of Economics and Behavioral Studies (ISSN: 2220-6140) \\ Vol. 9, No. 5, pp. 169-184, October 2017}

studies in developing countries. The exercise was repeated with additional prior of Sim's-Zha to compare whether or not the results differ. All four channels were again assessed and the findings are discussed below.

Figure 5: Interest Rate Channel - Sim's-Zha (WishartNormal)

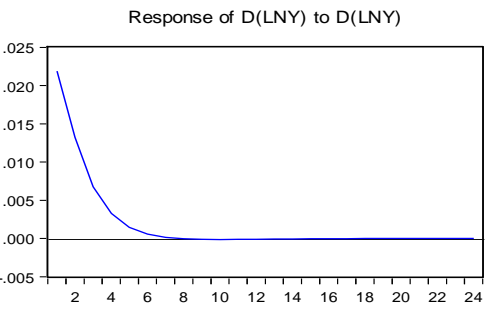

Response to Generalized One S.D. Innovations
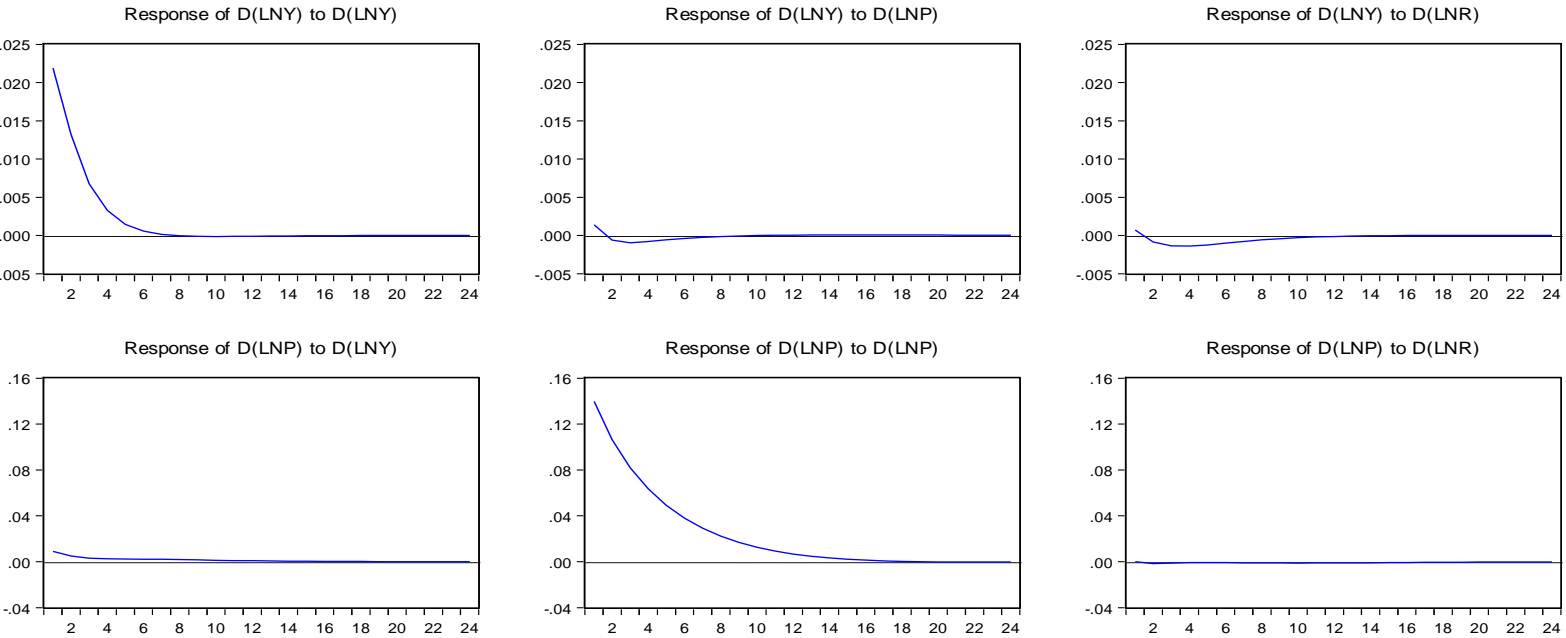

Response of $D(L N R)$ to $D(L N Y)$
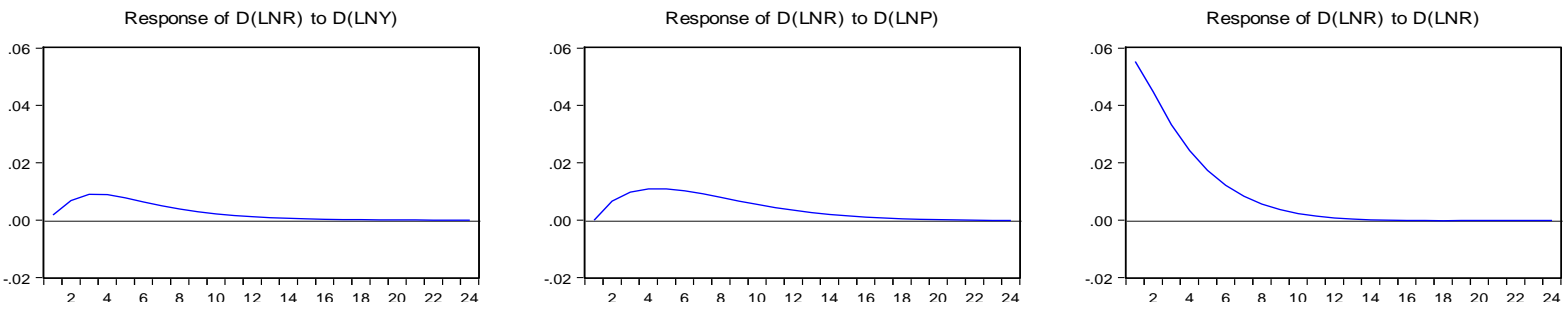

Figure 6: Exchange Rate Channel - Sim's-Zha (Wishart Normal)

Response to Generalized One S.D. Innovations

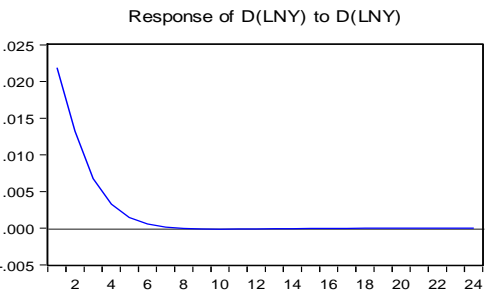

Response of $D(L N Y)$ to $D(L N P)$

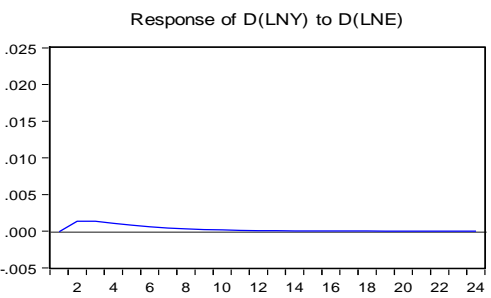

Response of $D(L N P)$ to $D(L N Y)$

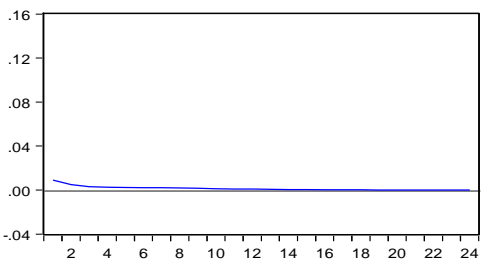

Response of $D(L N P)$ to $D(L N P)$
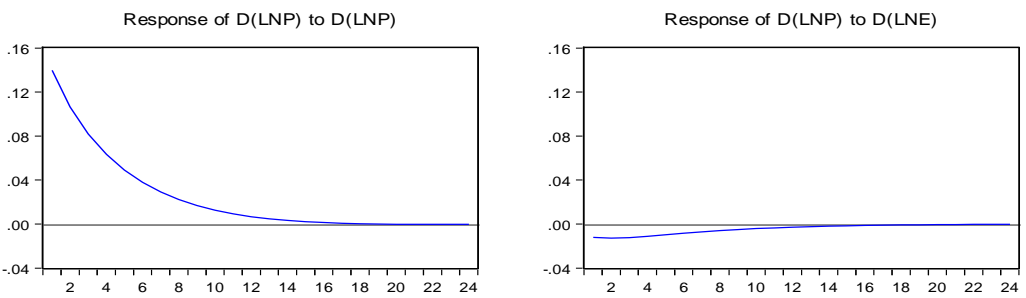

Response of $\mathrm{D}(\mathrm{LNE})$ to $\mathrm{D}(\mathrm{LNY})$
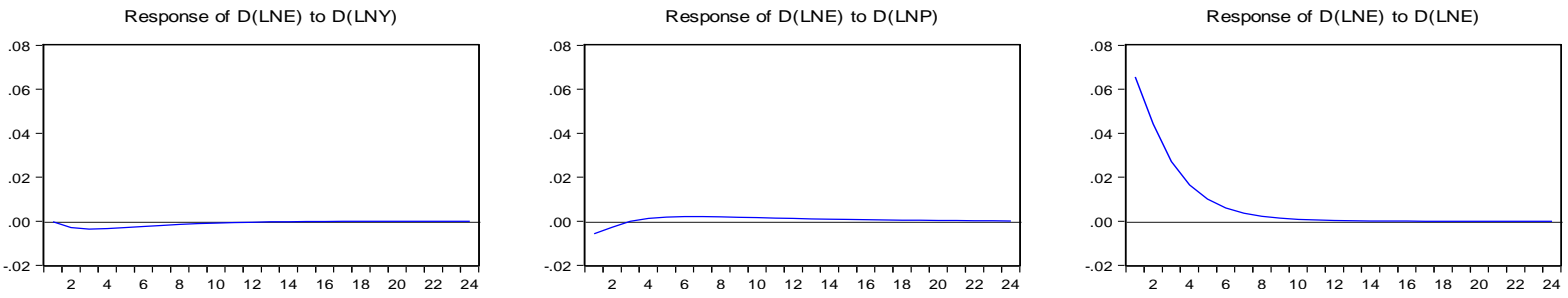
Figure 5 shows the results of the of impulse responses of output growth and inflation rate to interest rate innovation. In this regard, a positive shock in a form of a rise in the interest rate results in output growth decline up to 4 quarters. Thereafter, output increases to the baseline and the effects dies out after 15 quarters. Surprisingly, the shocks to interest rate did not affect the inflation rate under Sim's- Zha prior. This indicates that the monetary policy does have effect on inflation rate. The results in figure 6 show that the effects of positive exchange rate shock on output and inflation. In this instance, a positive shock to exchange rate (an appreciation of exchange rate in Namibia), results in an increase in output initially increases which followed by a non-persistent decline in output after 8 quarters. Similarly, an appreciation of exchange rate resulted in an increase in the inflation rate but on the negative grid, but the effects wore out 15 quarters under the Sim's-Zha prior.

Figure 7: Credit Channel - Sim's-Zha (Wishart Normal)

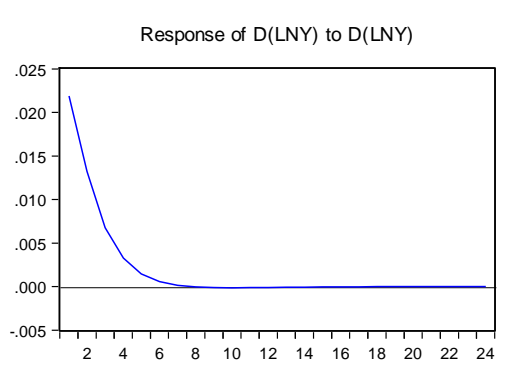

Response to Generalized One S.D. Innovations
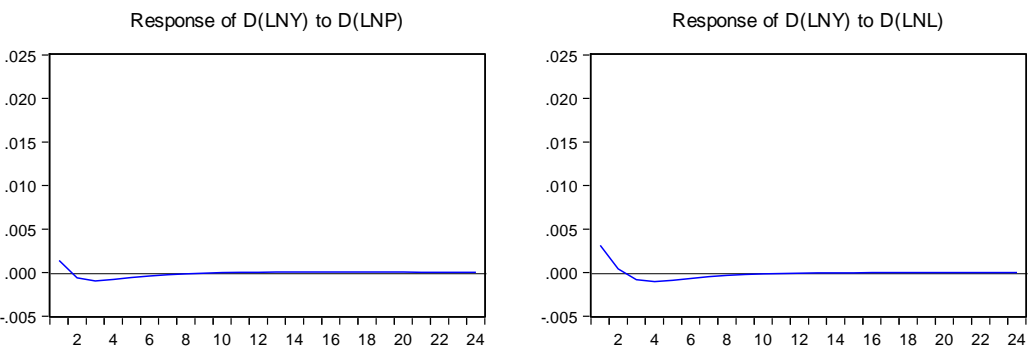

Response of $D(L N P)$ to $D(L N Y)$

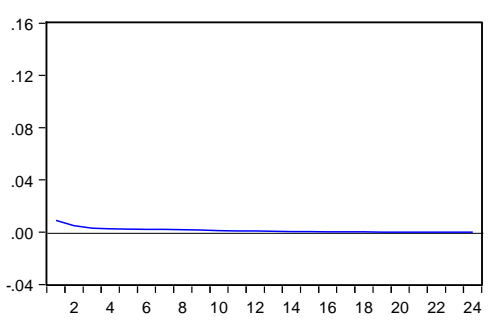

Response of $\mathrm{D}(\mathrm{LNP})$ to $\mathrm{D}(\mathrm{LNP})$

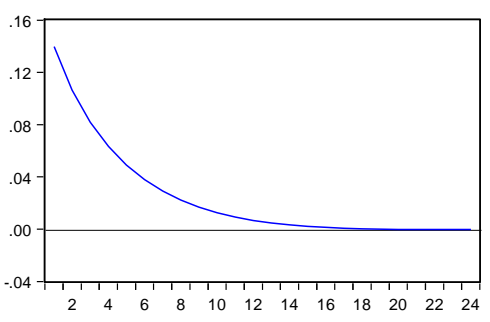

Response of $D(L N P)$ to $D(L N L)$
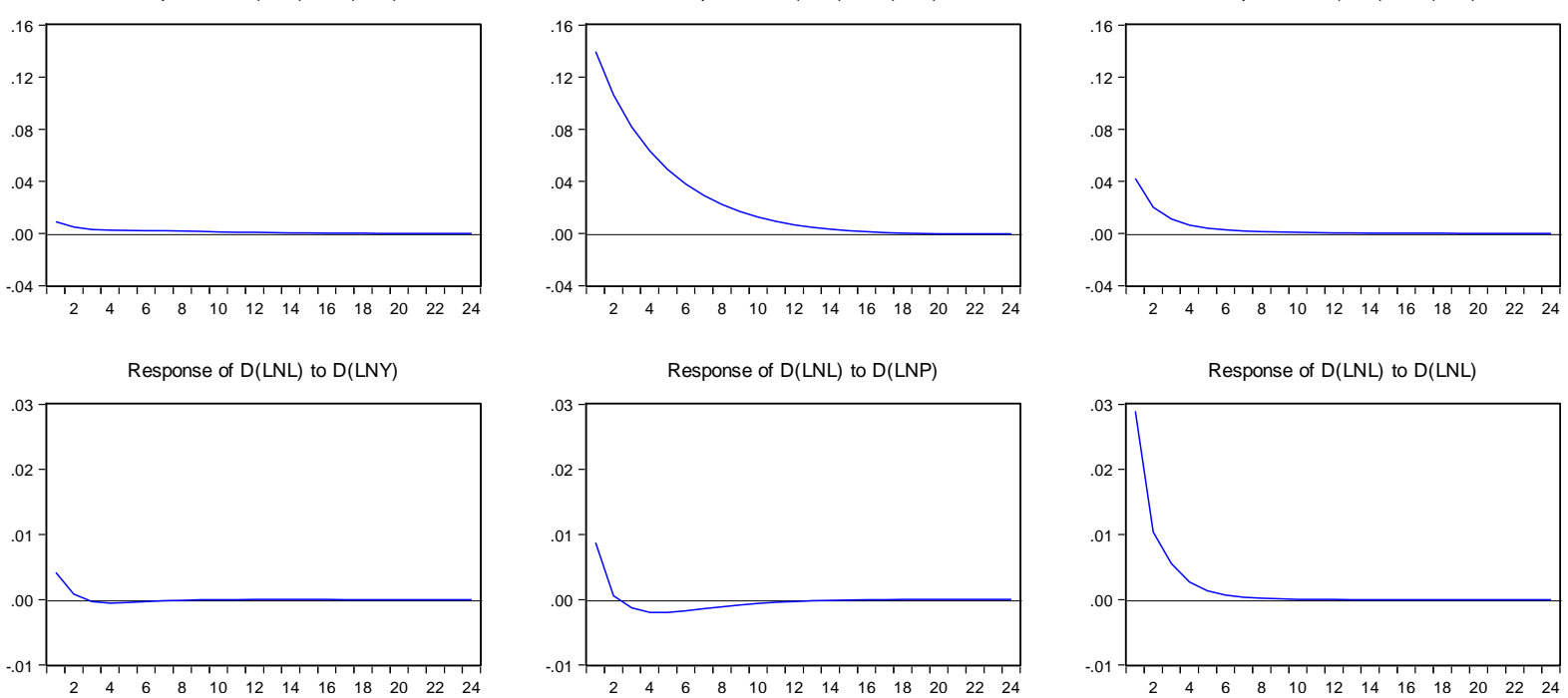

The results for the credit channel reveals that a positive shock to credit results in a decline in both output and inflation rate as shown in figure 7. Notably, the effects wear out after 8 and 7 for output and inflation respectively. Therefore, this illustrates the medium-term of monetary policy transmission mechanism as it is commonly recorded in literature for developing countries. Figure 8 reports that output responded immediately responded negatively to the shocks to housing prices but with a smaller magnitude. Moreover, inflation rate responded positively after 8 quarters, though the persistence dies out after 12 quarters though with relatively a smaller magnitude as it appear common in empirical studies in developing countries. 
Figure 8: Asset Price Channel - Sim's-Zha (Wishart Normal)

Response to Generalized One S.D. Innovations

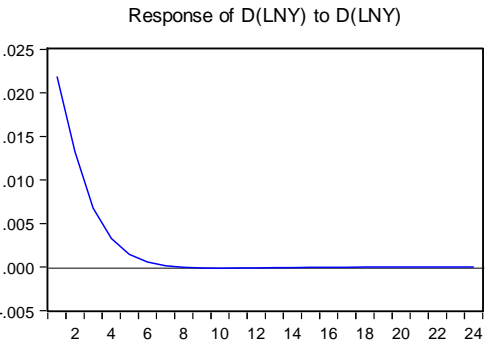

Response of $D(L N Y)$ to $D(L N P)$
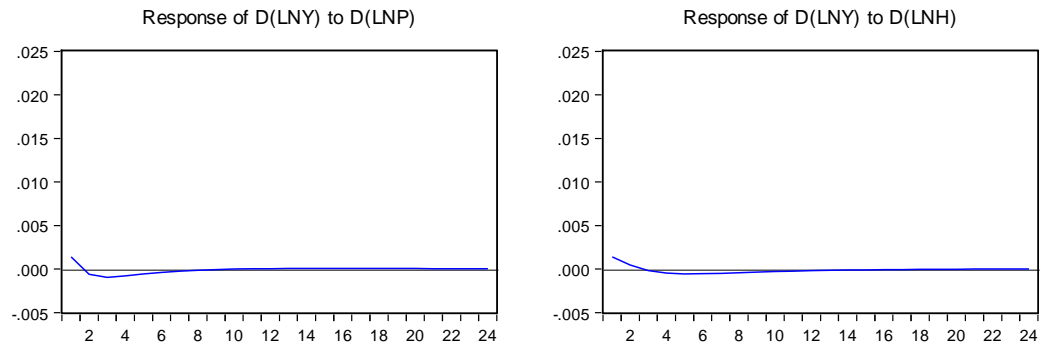

Response of $\mathrm{D}(\mathrm{LNP})$ to $\mathrm{D}(\mathrm{LNY})$

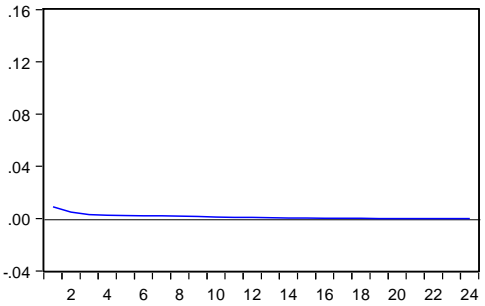

Response of $\mathrm{D}(\mathrm{LNP})$ to $\mathrm{D}(\mathrm{LNP})$

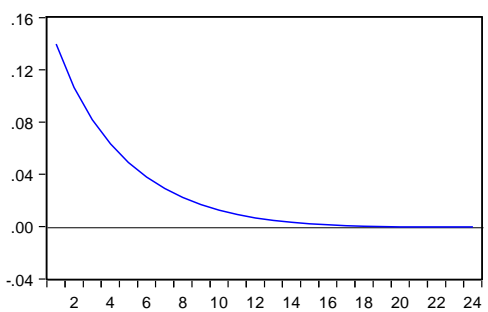

Response of $\mathrm{D}(\mathrm{LNP})$ to $\mathrm{D}(\mathrm{LNH})$

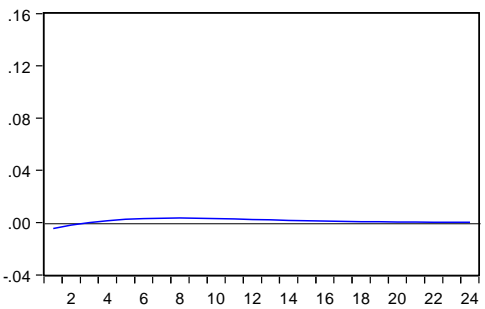

Response of $D(L N H)$ to $D(L N Y)$
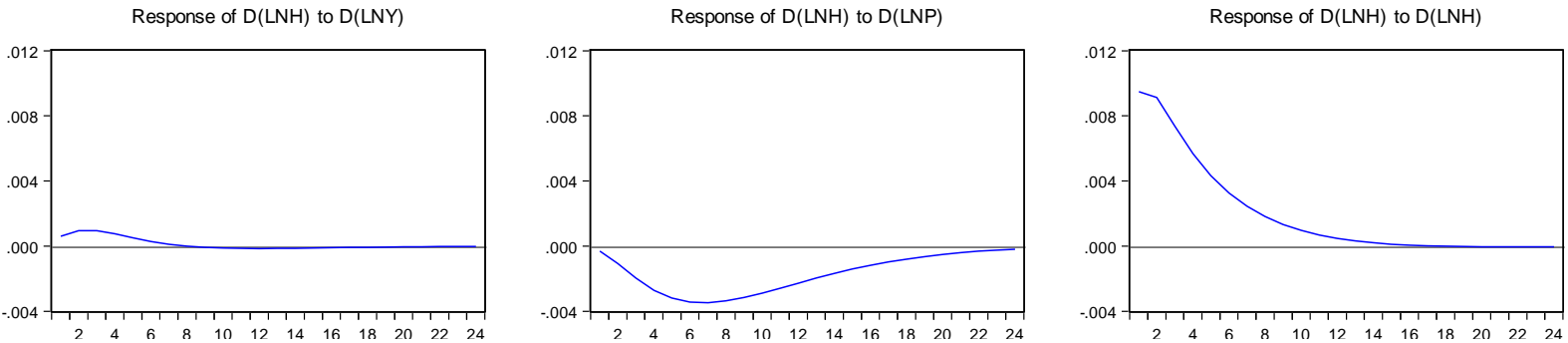

\section{Conclusion}

The study analyzed the various channels for monetary policy transmission mechanism in Namibia. The study utilized the Bayesian vector autoregression modeling approach where the impulse response functions and forecast error variance decomposition where derived. This approach was specifically chosen because of its appropriateness for small open economies where monetary policy has been criticized because of abnormalities such as liquidity as well as price or exchange rate puzzles. Firstly, the validity of the data used is checked and verified by using two sets of prior distributions suggested by Sims and Zha (1998) as well as prior distribution of Koop and Korobilis (2010). In this regard, quarterly data covering the period 2000:Q1 to 2016:Q4 was used in estimation of the models. The variables included are real gross domestic product (Y), the real effective exchange rate (expressed as an index, this index growth indicating Namibia's real appreciation against the currencies of the trading partners) (E), the inflation rate (P), the total credit extended to the private sector (L), the interest (repo rate) (R) and the real house prices index (H). The results of the unit root test showed that some variables are stationary at levels and others in first difference, implying that there is a mixture variables integrated of order zero I(0) and one I(1). The results of the impulse response functions showed that under the KoKo Minnesota/Litterman (2010) prior, the interest rate channel remains an important transmission mechanism of monetary policy shocks. However, the effect of monetary policy via the credit, exchange rate and asset price channels are short-lived. On the other hand, under the Sim's-Zha (Wishart-Normal) prior, the effect of the shocks to monetary policy remained persistent for about 12 quarters if not more. Therefore, the study recommends that all channels are to be considered in the conduct of monetary policy and not to primarily focus on the two channels namely, the interest rate and the credit channels. The asset price channel is very important for the stability of the financial market and consequently financial stability. 


\section{References}

Afandi, A. (2005). Monetary Policy Transmission Mechanism and Structural Breaks in Indonesia: (unpublished Doctoral Thesis, University of Wollongong, 2005).

Atabaev, N. \& Ganiyey, J. (2013). VAR Analysis of the Monetary Transmission Mechanism in Kyrgyzstan. Eurasian Journal of Business and Economics, 6(11), 121-134.

Bank of Namibia. (2000). Annual Reports. Windhoek.

Bernanke, B. S. \& Gertler, M. (1989). Agency Costs, Net Worth, and Business Fluctuations. American Economic Review, 79, 14-31.

Bitans, M., Stikuts, D. \& Tillers, I. (2003). The Monetary Transmission Mechanism in Latvia. Eesti Pank, Estonia. 109-130.

Boivin, J., Kiley, M. T. \& Mishkin, F. S. (2010). How has the Monetary Transmission Mechanism Evolved Over Time? National Bureau of Economic Research Working Paper 15879

Brandt, P. T. \& Freedman, J. R. (2006). Advances in Bayesian Time Series Modeling and the Study of Politics: Theory Testing, Forecasting, and Policy Analysis. Political Analysis, 14, 1-36.

Chow, H. K. (2004). A VAR Analysis of Singapore's Monetary Transmission Mechanism. Retrieved February 2, 2017, from http://ink.library.smu.edu.sg/soe_research/792

Gertler, M. \& Gilchrist, S. (1993). The Role of Credit Market Imperfections in the Monetary Transmission Mechanism: Arguments and Evidence. Scandinavian Journal of Economics, 95(1), 43-64

Goeltom, J. (2008).Transmission Mechanisms for Monetary Policy in Emerging Market Economies.BIS Papers No 35.

Gumata, N., Kabundi, A. \& Ndou, E. (2013). Important Channels of Transmission Monetary Policy Shock in South Africa. ERSA Working Paper 375.

Hai, B. V. \& Trang, T. T. M. (2015). The Transmission Mechanism of Monetary Policy in Vietnam: A VAR Approach. Graduate Institute of International and Development Studies Working Paper No 15-2015.

Huang, H. (2012). Monetary Policy, Balance-Sheets and Asset Prices: Transmission Mechanisms in U.S., EuroArea, Japan and China. China International Capital Corporation.

Jorgenson, D. W. (1963). Capital Theory and Investment Behavior. Chapter 1 in Dale W. Jorgenson (1996a).

Kalenga, P. (2001). Monetary Policy Framework in Namibia. Occasional Paper, Bank of Namibia.

Karamanou, P., Mahadeva, L., Robinson, P. \& Syrichas, G. (2017). Monetary Transmission Mechanism in Cyprus: A Fixed Exchange Rate Case. Retrieved February 2, 2017, from https://www.centralbank.gov.cy/media/pdf/mprpe_monetarytransmissionmechanismincy.pdf.

Koop, G. \& Korobilis, D. (2010). Bayesian Multivariate Time Series Methods for Empirical Macroeconomics. Foundations and Trends in Econometrics, 3(4), 267-358.

Mabulango, J. D. \& Boboy, Y. T. (2016). Monetary Policy Transmission Mechanism in DRC: A Bayesian VAR Analysis. LAREQ Working Paper III-001.

Metzler, A. H. (1995). Money Credit and (other) Transmission Processes: A Monetary Perspective. Journal of Economic Perspective, 9(4), 44-72.

Mishkin, F. S. (1978). Monetary Policy and Liquidity: Simulation Results. Economic Inquiry, 16(1), 16-36.

Mishkin, F. S. (1996). The Channels of Monetary Transmission: Lessons for Monetary Policy. NBER Working Paper No 5464.

Mishkin, F. S. (1998).The Dangers of Exchange-Rate Pegging in Emerging-Market Countries. International Finance, 1(1), 81-101.

Mishkin, F. S. (2004). The Economics of Money, Banking and Financial Markets and Institutions (4thed), Pearson Addison-Wesley: New York.

Muco, M., Sanfey, P. \& Taci, A. (2003). Inflation, Exchange Rates and the Role of Monetary Policy in Albania. European Bank for Reconstruction and Development. Working Paper No. 88

Mwabutwa, C. N., Viegi, N. \& Bittencourt, M. (2016). Evolution of Monetary Policy Transmission Mechanism in Malawi: A TVP-VAR Approach. Journal of Economic Development, 41(1), 33-55.

Ngalawa, H. P. E. (2009). Dynamic Effects of Monetary Policy Shocks in Malawi. Paper Presented at the 14th Annual Conference of the African Econometric Society, 8-10 July, Abuja, Nigeria.

Pedram, M., Shirinkakhsh, S. \& Afshar, A. (2011). The Role of House Prices in the Monetary Policy Transmission Mechanism in Iran: SVAR Approach and Counterfactual Simulation. Journal of Advanced Social Research, 1, 214-228. 


\section{Journal of Economics and Behavioral Studies (ISSN: 2220-6140)}

Vol. 9, No. 5, pp. 169-184, October 2017

Ramos-Francia, M. \& Sidaoui, J. J. (2008). The Monetary Transmission Mechanism in Mexico: Recent Developments. Bank for International Settlement Papers No 35.

Roley, V. V. \& Sellon, G. H. (1995). Monetary Policy Actions and Long-Term Interest Rates. Federal Reserve Bank of Kansas City. Economic Review, 80, 73-89.

Rosoiu, A. \& Rosoiu, I. (2013). Monetary Policy Transmission Mechanism in Emerging Countries. CrossCultural Management Journal, 1(3), 37-49.

Sims, C. A. \& Zha, T. (1998).Bayesian Methods for Dynamic Multivariate Models. International Economic Review, 39(4), 949-968.

Sheefeni, J. P. S. (2013). Monetary Policy Transmission in Namibia, 1993 - 2011: (unpublished Doctoral Thesis, Nelson Mandela Metropolitan University, 2013)

Spulbar, C., Nitoi, M. \& Stanciu, C. (2012). Monetary Policy Analysis in Romania: A Bayesian VAR approach. African Journal of Business Management, 6(36), 9957-9968.

Taylor, J. B. (1995). The Monetary Transmission Mechanism: An Empirical Framework. Journal of Economic Perspectives, 9(4), 11-26.

Tjirongo, M. T. (1995). Short -Term Stabilization Versus Long-Term Price Stability: Evaluating Namibia's Membership of the Common Monetary Area. Centre for the Study of African Economies WPS/95-18

Tobin, J. (1969). A General Equilibrium Approach to Monetary Theory. Journal of Money Credit and Banking, 1(1), 15-29.

Uanguta, E. \& Ikhide, S. (2002). Monetary Policy Transmission Mechanism in Namibia. Bank of Namibia Working Paper No.2/02.

Walsh, C. (2003). Monetary Theory and Policy (2nded), MIT Press. 